\title{
Pembelajaran Agama Katolik dengan Menggunakan Model Pembelajaran Quantum Teaching di SD Inpres Wairklau
}

\author{
Sipriana Oktavia \\ SD Inpres Wairklau, Maumere, Kab. Sikka, Nusa Tenggara Timur \\ Email: sipriana.oktavia@gmail.com \\ DOI : $10.32672 /$ jsa.v7i5.1532
}

\begin{abstract}
ABSTRAK
Tujuan penelitian ini adalah untuk mengetahui peningkatan hasil belajar Agama Katolik siswa kelas V SD Inpres Wairklau Maumere dengan menggunakan model pembelajaran Quantum Teaching. Penelitian ini menggunakan desain penelitian Kemmis dan Taggart yang terdiri atas dua siklus dan setiap siklus terdiri atas perencanaan, pelaksanaan tindakan dan observasi serta refleksi. Subjek penelitian ini adalah siswa kelas V SD Inpres Wairklau yang berjumlah 27 orang. Objek penelitian ini adalah hasil belajar Agama Katolik dan model Pembelajaran Quantum Teaching. Data dikumpulkan dengan menggunakan teknik tes dan instrumen penelitian berupa tes obyektif, dan data dianalisis dengan menggunakan statistik kuantitatif. Rata - rata hasil belajar yang dicapai siswa pada siklus I sebesar $62,25 \%$, dengan ketuntasan klasikal 17,5\% dan rata - rata hasil belajar pada siklus II sebesar $81,25 \%$ dan ketuntasan klasikal $87,5 \%$. Berarti telah terjadi peningkatan hasil belajar Agama Katolik dari siklus I ke Siklus II sebesar 18,99\% dan pingkatan hasil belajar ini sudah melebihi KKM yang ditetapkan yaitu 75. Dengan demikian dapat disimpulkan bahwa penerapan model Pembelajaran Quantum Teaching dapat meningkatkan hasil belajar Agama Katolik pada siswa kelas V SD Inpres Wairklau.

Kata Kunci : Hasil Belajar, Siswa, Model Pembelajaran Quantum Teaching
\end{abstract}

\section{PENDAHULUAN}

Pendidikan merupakan hubungan antarpribadi pendidik dan peserta didik. Hubungan ini disebut sebagai hubungan fungsional, yaitu pendidik sebagai pengajar dan peserta didik sebagai subjek belajar. Pendidikan ini dapat berlangsung di sekolah. Sekolah merupakan salah satu sarana yang dapat meningkatkan perkembangan pengetahuan peserta didik. Pengetahuan yang didapat peserta didik berupa pengetahuan intelektual dan pengetahuan religius. Pengetahuan intelektual dapat diterima dengan pelajaran-pelajaran secara umum, dan pengetahuan religius didapatkan melalui pelajaran agama. Pada kenyataanya pendidikan telah dilaksanakan semenjak adanya manusia, hakikatnya pendidikan merupakan serangkaian peristiwa yang komplek yang melibatkan beberapa komponen antara lain: tujuan, peserta didik, pendidik, isi atau bahan, cara/metode dan situasi/ lingkungan. Hubungan keenam faktor tersebut berkait satu sama lain dan saling berhubungan dalam suatu aktifitas satu pendidikan.

Kegagalan pengajaran agama Katolik dapat terjadi karena guru agama yang kurang mempersiapkan diri. Selain itu guru merasa sudah dapat mengajar dengan baik, sehingga banyak pendidik yang suka mengajar dengan jalan pintas, tidak mempersiapkan 


\section{Selestina Vinsensia}

perencanaan pembelajaran, tidak mampu mengimplemintasikan metode atau model pembelajaran dengan situasi dan kebutuhan peserta didik, sehingga pembelajaran yang berlangsung bersifat monoton dan membosankan, sehingga hasil belajar yang diharapkan baik menjadi tidak sesuai dengan harapan. Keberhasilan proses pembelajaran khususnya agama Katolik tidak terlepas dari kemampuan guru dalam upaya mengembangkan modelmodel pembelajaran yang berorentasi pada peningkatan intensitas keterlibatan siswa secara efektif di dalam proses pembelajaran. Pengembangan model pembelajaran yang tepat pada dasarnya bertujuan untuk menciptakan kondisi pembelajaran yang memungkinkan peserta didik belajar secara aktif dan menyenangkan sehingga peserta didik dapat meraih belajar dan prestasi yang optimal. Pendidik dapat memilih beberapa model ataupun metode pembelajaran yang membantu pelaksanaan pembelajaran agar berjalan dengan baik. Untuk dapat mengembangkan model pembelajaran yang efektif maka setiap pendidik sebaiknya memiliki pengetahuan yang memadai berkenan dengan konsep dan cara mengimplemensentasikan model-model tersebut dalam pembelajaran.

Berdasarkan pengalaman dan kenyataan yang di hadapi oleh peneliti , dalam hal ini sebagai guru mata pelajaran Agama Katolik pada SD Inpres Wairklau dapat ditemukan hal-hal sebagai berikut: (1) saat proses pembelajaran berlangsung siswa cenderung bermain-main dengan temannya tanpa memperhatikan penjelasan guru dan saat guru mengajukan pertanyaan siswa tidak dapat menjawab sehingga tercermin interaksi dalam kelas itu rendah, (2) kurangnya kerjasama antar siswa saat proses pembelajaran berlangsung. Hal ini, dapat menimbulkan egoisme pada diri siswa, (3) interaksi siswa dalam proses pembelajaran baik antara siswa dengan siswa, maupun siswa dengan guru, masih rendah. Hal ini dapat dilihat dari kurangnya kemauan siswa untuk mengajukan maupun menjawab pertanyaan dari guru yang bersangkutan, (4) sebagian besar siswa merasa bahwa mata pelajaran Agama Katolik cenderung membosankan karena didominasi oleh hafalan.

Dalam pendidikan Agama Katolik, Pendekatan Pembelajaran lebih ditekankan pada pendekatan yang didalamnya terkandung 3 proses yaitu proses pemahaman, pergumulan dan penghayatan iman dalam konteks hidup nyata sehari-hari. Proses pembelajaran Pendidikan Agama Katolik dimulai dari penggalian dan pendalaman pengalaman hidup sehari-hari, diteguhkan dalam terang Kitab Suci / ajaran Gereja, yang pada akhirnya diwujudnyatakan dalam tindakan konkrit sehari-hari. Pendidikan Agama Katolik (PAK) pada dasarnya bertujuan agar peserta didik memiliki kemampuan untuk membangun hidup yang semakin beriman. Membangun hidup beriman Kristiani berarti membangun kesetiaan pada Injil Yesus Kristus, yang memiliki keprihatinan tunggal, yakni Kerajaan Allah. Diharapkan dengan pengguaan model pembelajaran quantum teaching dalam pembelajarn agama katolik dapat megatasi persoalan diatas, yaitu rendahnya hasil belajar siswa. Menurut Gagne (dalam Suprijono, 2009: 5), hasil belajar berupa : 1) informasi verbal yaitu kapasitas mengungkapkan pengetahuan dalam bentuk bahasa, baik lisan maupun tertulis, 2) keterampilan intelektual yaitu kemampuan mempresentasikan konsep dan lambing, 3) strategi kognitif yaitu kecakapan menyalurkan dan mengarahkan aktivitas kognitifnya sendiri, 4) keterampilan motorik yaitu kemampuan melakukan serangkaian gerak jasmani dalam urusan dan koordinasi, sehingga terwujud otomatisme gerak jasmani, 5) sikap adalah kemampuan menerima atau menolak objek berdasarkan 
penilaian terhadap objek tersebut. Sikap merupakan kemampuan menjadikan nilai-nilai sebagai standar perilaku. Dengan model yang tepat dalam pembelajaran agama katolik diharapkan dapat diperbaiki. Salah satu model pembelajaran yang dapat meningkatkan semangat belajar, tanggung jawab dan berkomitmen terhadap pembelajaran adalah dengan pembelajaran quantum teaching (Yuhasriati, 2016).

Berdasarkan uraaian di atas maka tujuan penelitian ini untuk mengetahui peningkatan hasil belajar siswa pada pelajaran Pendidikan Agama katolik dengan menggunakan model pembelajaran Quantum Teaching pada siswa kelas V SD Inpres Wairklau.

\section{METODE PENELITIAN}

Jenis penelitian ini adalah penelitian tindakan kelas (PTK). Pada penelitian tindakan kelas ini digunakan model Kemmis dan Mc Taggart, pelaksanaan penelitian terdiri dari dua siklus. Penelitian dilaksanakan pada Agustus- September 2019 di kelas V SD Inpres Wairklau. Subyek dalam penelitian ini adalah siswa-siswi kelas V SD Inpres Wairklau pada tahun 2019/2020 dengan jumlah siswa 27 siswa. Prosedur penelitian ini dilaksanakan sesuai dengan yang dikembangkan oleh Kemis dan Mc Taggart maka prosedur penelitian ini dalam bentuk siklus dalam perencanaan penelitian ini akan dilaksanakan dalam dua siklus, Siklus I dan Siklus II dengan tahap-tahapnya adalah Perencanaan, Pelaksanaan dan Observasi serta Refleksi.

Metode pengumpulan data dalam penelitian ini adalah dengan menggunakan metode tes. Instrumen penelitian adalah alat yang digunakan untuk mengumpulkan data penelitian. Dalam penelitian ini instrument yang di gunakan adalah soal tes. Bentuk Tes adalah tes pilihan Ganda I sebanyak 10 nomor. Dan Pada Siklus II sebanyak 10 nomor. Dengan Maksimal Skor 100 dan minimal Skor 0. Metode analisis data yang digunakan pada penelitian tindakan kelas ini digunakan analisis statistik deskriptif kuantitatif yakni suatu metode penelitian yang bersifat menggambarkan kenyataan atau fakta sesuai dengan data yang diperoleh dengan tujuan untuk mengetahui hasil belajar Agama Katolik yang dicapai siswa, yang mengukur dengan menghitung Mean (rata-rata)

Menghitung rata-rata persentase, Kriteria Penggolongan Hasil Belajar dengan standar PAP, Menentukan Kriteria Keberhasilan Tindakan. Penelitian ini dikatakan berhasil apabila rata-rata nilai prestasi belajar siswa dalam satu kelas berada pada klasifikasi tinggi atau berada pada presentase nilai tertinggi. Berdasarkan kriteria ketuntasan minimal yaitu 75

\section{HASIL PENELITIAN}

Sebelum melaksanakan penelitian dengan menggunakan model pembelajaran quantum teaching, rata - rata hasil belajar Agama Katolik Semester I Kelas V SD Inpres Wairklau masih sangat rendah. Dari data tes hasil belajar pada kegiatan pra tindakan diperoleh nilai rata - rata hasil belajar sebesar 61,25. Dari nilai yang diperoleh menunjukan bahwa hasil belajar agama katolik belum mencapai KKM yang ditetapkan yaitu 75. Dari hasil tes awal penulis menyimpulkan bahwa pemahaman siswa terhadap materi masih sangat rendah. Hal ini disebabkan oleh beberapa faktor antara lain : (1) 


\section{Selestina Vinsensia}

informasi tentang urutan pembelajaran kurang jelas, karena guru menjelaskan materi secara umum dan langsung memberikan tugas untuk dikerjakan siswa sehingga hasil yang di peroleh tidak sesuai KKM yang ditetapkan, (2) murid kurang aktif untuk bertanaya tentang materi yang di pelajari, (3) murid kurang aktif dalam mengerjakan tugas yang diberikan.

Peneliti menemukan bahwa selama proses pembelajaran berlangsung permasalahan yang terjadi bukan hanya terdapat pada murid saja melainkan juga pada guru yang kurang menggunakan pola pembelajaran yang bervariasi, sehingga proses pembelajaran menjadi sangat monoton dan membosankan. Hal ini berdampak pada hasil belajar siswa yang tidak maksimal. Dari Hasil Tes awal diatas dirancang tindak lanjut yang bertujuan untuk memperbaiki hasil belajar Agama Katolik siswa dengan menggunakan model pembelajaran yang dipilih dalam penelitian ini yaitu model pembelajaran quantum taching Berdasarkan refleksi awal hasil belajar siswa yang masih rendah dan belum mencapai KKM yang ditetapkan maka kegiatan penelitian pada tahap pertama dilaksanakan sesuai dengan prosedur penelitian yang berawal dari perencanaan, pelaksanaan dan observasi serta refleksi.

Berdasarkan hasil analisis data, diperoleh rata - rata hasil belajar Agama Katolik Siklus I $=62,26$, persentase 62,26\% berdasarkan hasil analisis data, dapat diketahui bahwa rata - rata hasil belajar Agama Katolik Siklus II $=81,25$, persentase $81,25 \%$ termasuk dalam kategori tinggi. Analisis data hasil belajar agama katolik siklus I dan II dapat dilihat pada tabel di bawah ini.

Tabel 1. Hasil belajar PAK Siklus I dan Siklus II

\begin{tabular}{ccc}
\hline \multirow{2}{*}{ DATA } & \multicolumn{2}{c}{ HASIL BELAJAR } \\
\cline { 2 - 3 } & SIKLUS I & SIKLUS II \\
\hline Rata-rata & 62,26 & 81,25 \\
\hline Kategori & Rendah & Tinggi \\
\hline Persentase & $62,26 \%$ & $81,25 \%$ \\
\hline Ketuntasan klasikal & $17,5 \%$ & $87,5 \%$ \\
\hline Kenaikan rata-rata & Siklus I ke Siklus II $=18,99 \%$ \\
\hline
\end{tabular}

Berdasarkan uraian hasil analisis data dan tabel di atas dapat dikatakan bahwa hasil belajar Agama Katolik siswa kelas V SD Inpres Wairklau mengalamai peningkatan dari siklus I ke Siklus II sebesar 18,99\% dan ketuntasan klasikal pada siklus I sebesar 17,5\% mengalami peningkatan di siklus II yaitu mencapai $87,5 \%$. Hal ini membuktikan bahwa penggunaan model pembelajaran yang tepat dapat mengatasi masalah rendahnya hasil belajar siswa. Dalam penelitian ini penggunaan model pembelajaran Quantum Teaching dapat dikatakan dapat memperbaiki hasil belajar siswa. Model pembelajaran quantum memili kelebihan yang dapat membimbing siswa ke arah berpikir yang sama dalam satu saluran pikiran yang sama, lebih melibatkan siswa, saat proses pembelajaran perhatian siswa dapat dipusatkan kepada hal-hal yang dianggap penting oleh guru sehingga hal yang penting itu dapat diamati secara teliti, karena gerakan dan proses dipertunjukkan maka tidak memerlukan keterangan-keterangan yang banyak, proses pembelajaran menjadi lebih 
nyaman dan menyenangkan, siswa didorong untuk aktif mengamati, menyesuaikan antara teori dengan kenyataan dan dapat mencoba melakukannya sendiri.

Dengan kelebihan yang dimiliki dalam model pembelajaran quantum teaching dibutuhkan kreativitas dari seorang guru untuk merangsang keinginan bawaan siswa untuk belajar, secara tidak langsung guru terbiasa untuk berfikir kreatif setiap harinya, yang akirnya akan berdampak pelajaran yang diberikan oleh guru mudah diterima atau dimengerti oleh siswa sehingga tujuan dari pembelajaran yang diharapkan dapat diperoleh yang muaranya adalah hasil belajar siswa dapat meningkat sesuai dengan harapan dari pendidik maupun peserta didik.

Sejalan dengan teori-teori pendukung dan penelitian-penelitian terdahulu yang menggunakan model pembelajaran Quantum Teaching yang menjadi refrensi dan acuan dalam penelitian ini ditemukan bahwa penggunaan model Quantum Teaching dapat meningkatkan hasil belajar agama katolik siswa terbukti secara empirik dalam penelitian ini. Berdasarkan deskripsi analisis hasil penelitian diperoleh data bahwa hasil belajar siswa telah mencapai kriteria yang ditentukan. Dengan demikian dapat dinyatakan penerapan model pembelajaran Quantum Teaching dapat meningkatkan hasil belajar Agama Katolik siswa kelas V SD Inpres Wairklau.

\section{Kesimpulan}

Penggunaan model pembelajaran Quantum Teaching dapat meningkatkan hasil belajar Agama Katolik pada siswa kelas V SD Inpres Wairklau. Rata - rata hasil belajar yang dicapai siswa pada siklus I sebesar $62,26 \%$, dengan ketuntasan klasikal 17,5\% dan pada siklus II rata - rata hasil belajar siswa sebesar 81,25\% dan ketuntasan klasikal 87,5\%. Berarti telah terjadi peningkatan rata - rata hasil belajar Agama Katolik dari siklus I ke Siklus II sebesar 18, 99\% dan pingkatan hasil belajar ini sudah melebihi KKM yang ditetapkan yaitu 75. Dengan demikian dapat disimpulkan bahwa penerapan model pembelajaran Quantum Teaching dapat meningkatkan hasil belajar Agama Katolik siswa kelas V SD Inpres Wairklau.

\section{PENUTUP}

\section{Kesimpulan}

Penggunaan model pembelajaran Quantum Teaching dapat meningkatkan hasil belajar Agama Katolik pada siswa kelas V SD Inpres Wairklau. Rata - rata hasil belajar yang dicapai siswa pada siklus I sebesar $62,26 \%$, dengan ketuntasan klasikal 17,5\% dan pada siklus II rata - rata hasil belajar siswa sebesar 81,25\% dan ketuntasan klasikal 87,5\%. Berarti telah terjadi peningkatan rata - rata hasil belajar Agama Katolik dari siklus I ke Siklus II sebesar 18, 99\% dan pingkatan hasil belajar ini sudah melebihi KKM yang ditetapkan yaitu 75. Dengan demikian dapat disimpulkan bahwa penerapan model pembelajaran Quantum Teaching dapat meningkatkan hasil belajar Agama Katolik siswa kelas V SD Inpres Wairklau.

\section{DAFTAR PUSTAKA}

A'la, Miftahul, 2012. Quantum Teaching. Jogjakarta: Diva Press 
Selestina Vinsensia

Asrori, Mohammad, 2009. Penelitian Tindakan Kelas. Bandung: CV Waca Prima.

Dewi Sartika Simbolan. 2015. Peningkatan Hasil Belajar Agama KatolikMelalui Pembelajaran Quantum Teaching Pada Siswa Kelas V SD Negeri 060869

Gaharu, Medan Timur. Jurnal Pena Edukasi, Vol. 3 No. 6, Nopember 2016. https://docplayer.info/52303507-Peningkatan-hasil-belajaragama-katolik-melalui-pembelajaran-quantum-teaching.html

Kusumah, Wjaya dan Dwitagama, Dedi: 2010. Penelitian Tidakan Kelas. Jakarta: PT Indeks.

Gulo, W. 2002. Strategi Belajar Mengajar. Jakarta: Grasindo

Hamalik, O. 2015. Kurikulum dan Pembelajaran. Jakarta: PT Bumi Aksara

Hamdani. 2011. Strategi Belajar Mengajar. Bandung : Pustaka Setia.

Hardini, I. dan Puspita, D. (2012) Strategi Pembelajaran Terpadu. Yogyakarta:

Familia

Kusmawati, R. Omegawati, W, H. 2010. PR Biologi Untuk SMA/MA Kelas X/2Kalten: Intan Pariwara.

Lutfi. 2007. Strategi Pembelajaran Biologi Teori, Praktik dan Penelitian. UNP Press: Padang

Yuhasriati, Yuliani (2016). Hasil Belajar Persamaan Linear satu variabel dengan Quantum Teaching. Availiable at : http://www.ojs.serambimekkah.ac.id/index.php/serambiakademika/article/view/279 